\title{
PERPUSTAKAAN NASIONAL REPUBLIK INDONESIA SEBAGAI SUMBER COPY CATALOGING
}

\author{
Arief Wicaksono*
}

Pengutipan: Wicaksono, A. (2016). Perpustakaan Nasional Republik Indonesia sebagai sumber copy cataloging. Khizanah Al-Hikmah Jurnal Ilmu Perpustakaan, Informasi, dan Kearsipan, 4(2), 140151.
*Mahasiswa Magister Departemen Ilmu Perpustakaan dan Informasi Universitas Indonesia, dan Pustakawan di Perpustakaan Nasional RI
(arief.wicaksono41@ui.ac.id, arief_wicaksono@perpusnas.go.id)

\begin{abstract}
ABSTRAK
Pengatalogan salin merupakan proses menyalin metadata dari cantuman bibliografi yang ada. Istilah ini berkembang karena adanya perpustakaan yang mempunyai koleksi yang sama. Untuk menghindari pekerjaan duplikasi, maka dilakukan pengatalogan salin. Di Indonesia, Perpustakaan Nasional dapat menjadi sumber pengatalogan salin bagi perpustakaan lainnya. Hal ini dimungkinkan karena Perpustakaan Nasional yang juga berfungsi dengan lembaga deposit dalam pengawasan bibliografi nasional. Tujuan penelitian ini adalah untuk melihat bagaimana sumber pengatalogan salin yang disediakan Perpustakaan Nasional dan sejauh mana sumber pengatalogan salin tersebut sudah digunakan. Untuk mendapatkan data sesuai tujuan penelitian dilakukan studi kualitatif dari sumber pengatalogan salin Perpustakaan Nasional. Selain itu juga dilakukan wawancara berdasarkan prinsip snowball sampel dan studi dokumen terutama dokumentasi online dari web sumber pengatalogan salin Perpustakaan Nasional. Hasilnya, sumber pengatalogan salin Perpustakaan Nasional adalah katalog online, Katalog Induk Nasional, dan Bibliografi Nasional Indonesia yang dapat. Kecuali Bibliografi Nasional Indonesia, sumber pengatalogan salin tersebut mempunyai fitur unduh metadata cantuman bibliografi minimal dengan format MARC dan XML. Agar digunakan sumber pengatalogan salin, Perpustakaan Nasional melakukan sosialisasi dan bimbingan teknis pengatalogan salin yang menyatu dalam fungsi e-library. Ditemukan sudah terdapat beberapa perpustakaan yang menggunakan sumber pengatalogan salin Perpustakaan Nasional untuk melakukan pengatalogan salin di perpustakaannya. Namun seperti kondisi umum di dunia perpustakaan, Pengatalogan salin yang mempunyai kelebihan tidak banyak dilakukan oleh perpustakaan.
\end{abstract}

Kata Kunci: Pengatalogan salin, Perpustakaan Nasional Republik Indonesia

\section{ABSTRACT}

Copy cataloging is a process to copy metada from one to other library catalogs. The study found that the sources for copy cataloging from the National library are online catalog, National Main Catalog (Katalog Induk Nasional), and Indonesian National Bibliography (Bibliografi Nasional Indonesia). For Indonesian National Bibliography, its copy cataloging has minimum download fiture in MARC and XML format. In order to be used widely, the National Library have promoted and conducted short workshops on copy cataloging along with e-library function. The study also found that there were libraries that have used its national library fiture into their libraries. However, as a general case in Indonesian libraries, copy cataloging, in which it has advantages, still remains lack of use for many libraries.

Key words: Copy cataloging, National library of Indonesia 


\section{PENDAHULUAN}

\section{a. Latar Belakang}

Pengatalogan salin adalah terjemahan dari istilah copy cataloging. Pengatalogan salin adalah proses menyalin metadata dari suatu cantuman bibliografi. Kegiatan ini sangat membantu bagi perpustakaan yang terbatas sumber daya manusianya. Dengan pengatalogan salin, pustakawan di perpustakaan tersebut dapat melakukan proses pengatalogan dokumen dengan lebih cepat selama metadata cantuman bibliografi dari dokumen yang sedang diolah ada dalam lembaga informasi atau perpustakaan yang memang menyediakan layanan pengatalogan salin.

Kegunaan pengatalogan salin ini tidak hanya berlaku bagi perpustakaan yang terbatas sumber daya manusianya, perpustakaan yang cukup dalam hal sumber daya manusia juga akan mendapatkan kegunaan pengatalogan salin. Pengatalogan salin ini membuat proses pengatalogan dari suatu perpustakaan menjadi lebih efektif dan efisien. Efektif karena tidak perlu melakukan pekerjaan yang memang sudah dikerjakan oleh orang lain dalam hal ini perpustakaan lain. Efisien karena akan memangkas biaya pengatalogan, misalnya tidak diperlukan terlalu banyak pustakawan untuk melakukan pengolahan. Pengatalog dapat memfokuskan pada hal lain yang mungkin belum dikerjakan karena masalah waktu.

Hess (2015) melakukan penelitian tentang pengatalogan salin untuk koleksi DVD di perpustakaan University of San Diago. Hess menyatakan setelah memberlakukan prosedur baru pengatalogan salin, pengatalog tidak lagi menghabiskan seharian penuh untuk mengerjakan satu DVD. Pengatalog sekarang dapat membantu pengatalogan original untuk koleksi tesis dan disertasi yang mulai menumpuk.

Pemangkasan biaya pengatalogan dan juga kelebihan lain pengatalogan salin juga dimungkinkan di Indonesia. Hal ini terjadi karena salah satu sumber pengatalogan salin, yaitu Perpustakaan Nasional Republik Indonesia (selanjutnya ditulis Perpusnas) memang membuka metadata cantuman bibliografinya secara gratis di katalog online. Selain itu, Perpusnas juga membangun jejaring katalog yang dimiliki perpustakaanperpustakaan yang ada di Indonesia, yaitu melalui Katalog Induk Nasional (KIN) online dan Bibliografi Nasional Indonesia (BNI) online.

Pengatalogan salin ini menarik perhatian peneliti yang sebenarnya dapat dikatakan sebagai 'pustakawan layanan' karena sehari-hari ditempatkan di bagian layanan. Ketertarikan ini disebabkan kondisi bahwa walaupun pengatalogan berada di belakang meja, namun hasilnya ikut menentukan kondisi layanan suatu perpustakaan. Hess (2015) menyatakan bahwa:

"The catalog truly is the foundation of the library. When any change is made, whether to the interface or to the policy underlying it, it affects everyone who works at or uses the library."

\section{b. Tujuan Penelitian}

Penelitian ini bertujuan memahami sumber pengatalogan salin yang disediakan oleh Perpusnas dan sejauh mana sumber pengatalogan salin tersebut telah digunakan. 


\section{c. Metode Penelitian}

Penelitian menggunakan pendekatan Setelah mengidentifikasi dengan kualitatif. sumber pengatalogan salin yang disediakan Perpusnas, pengumpulan data dilakukan melalui penggambaran secara kualitatif terhadap sumber tersebut. Pengumpulan data juga dilakukan melalui wawancara kepada beberapa informan yang dinilai mampu menjelaskan mengenai pengatalogan salin di Perpusnas. Informan dipilih berdasarkan prinsip snowball sampling. Informan awal ditentukan peneliti, namun informan selanjutnya didasarkan pada rujukan dari informan awal dan informan selanjutnya. Selain itu juga dilakukan studi dokumentasi terutama dokumentasi online yang terdapat dalam web terkait pengatalogan salin yang dikelola Perpusnas.

Keterbatasan penelitian ini adalah untuk melihat sejauh mana sumber pengatalogan salin Perpusnas telah digunakan hanya merujuk berdasarkan informasi dari Perpusnas. Dalam penelitian ini tidak dilakukan pengecekan pada perpustakaan yang disebutkan telah menggunakan sumber pengatalogan salin Perpusnas. Hal ini dilakukan berdasarkan keterbatasan peneliti. Selain itu, kajian ini tidak bersifat teknis bagaimana melakukan pengatalogan salin yang membutuhkan kemampuan teknis tersendiri.

\section{TINJAUAN LITERATUR}

Schultz pengatalogan merupakan bibliografi tanpa referensi ke cantuman bibliografi untuk dokumen yang sama atau untuk dokumen yang sama namun beda edisi (Bapte, 2015). Lebih lanjut Schultz mengatakan pengatalogan merujuk kepada pengatalogan dokumen dengan memeriksa bagian tertentu dokumen tersebut untuk mendapatkan informasi yang diperlukan sehingga dapat mendeskripsikan dokumen. Pengatalogan ini seringkali dilakukan pada dokumen yang unik. Unik di sini dalam arti kecil kemungkinannya dimiliki oleh perpustakaan lain.

Menurut Svenonius (2000), pengatalogan (atau dalam istilah lain Svenonius: organising information) terlihat tidak ada bedanya dari mengorganisasikan yang lainnya. Namun ada perbedaan yang penting, yaitu terdapatnya kompleksitas yang unik pada organisasi informasi. Dalam pengatalogan terdapat dua entitas yang berbeda yang perlu diorganisasikan secara bersamaan dan dengan menghargai keduanya, yaitu karya (works) dan dokumen perwujudannya.

Lalu pada kenyataannya, dokumen yang sama tersedia di beberapa perpustakaan. Masing-masing perpustakaan melakukan pengatalogan untuk dokumen yang sama tersebut. Dari kedua hal ini, kekompleksitas pengatalogan dan terdapat dokuman yang sama dalam perpustakaan, maka muncul ide untuk melakukan pengatalogan salin. Dengan memanfaatkan kemajuan teknologi, maka perpustakaan dapat melakukan pengatalogan salin. Perpustakaan yang melakukan pengatalogan salin dapat memasukkan cantuman bibliografi tanpa benar-benar mengetikkan. Namun sayangnya pengatalogan salin ini kurang dimanfaatkan hingga saat ini (Bapte, 2015).

Pada gambar 1 tergambar alur kerja 
perpustakaan yang menggunakan pengatalogan salin dalam proses pengatalogannya. Ketika bahan perpustakaan sampai pada proses pengatalogan, pengatalog akan mencari terlebih dahulu di sumber pengatalogan salin. Jika sumber sudah menyediakan cantuman bibliografi bahan perpustakaan tersebut maka dilakukan proses pengatalogan salin. Jika tidak baru dilakukan proses pengatalongan original mulai dari pengatalogan deskriptif dan pengatalogan subjek. Dalam pengatalogan salin, cukup dilakukan proses penyalinan metadata dari cantuman bibliografi lalu dilakukan pengunggahan metadata tersebut ke pangkalan data perpustakaan. Alur selanjutnya adalah pengecekan apakah diperlukan penambahan data terkait kebijakan lokal perpustakaan. Jika tidak ada, maka pengatalog dapat langsung menyimpan data tersebut. Dari proses ini terlihat akan ada banyak waktu yang terhematkan dan mengurangi beban kerja dalam mengorganisasikan informasi.

Kelebihan pengatalogan salin, menurut Bapte (2015) adalah tidak memerlukan pengetikan cantuman bibliografi oleh pengatalog, menawarkan kesempatan penghindaran kesalahan pengetikan karena seluruh cantuman disalin, data yang disalin lebih ilmiah karena disalin dari sumber terpercaya, dan mempromosikan sharing sumber. Disamping mempunyai kelebihan, pengatalogan salin juga mempunyai masalah dalam penerapannya, yaitu kemampuan teknis tertentu diperlukan dan adanya kemungkinan kesalahan dalam pemberian kode MARC.

Mustafa dan Rahardjo (2011) menyatakan banyak di negara Eropa dan Amerika Utara sudah sejak lama mengembangkan dan memanfaatkan konsep layanan pengatalogan salin.
Layanan ini tidak selalu disediakan oleh perpustakaan nasional negara tersebut, namun juga dapat dilakukan oleh instansi lain, seperti Birmingham Library Center Management Project dan Online Catalog Library Center. 


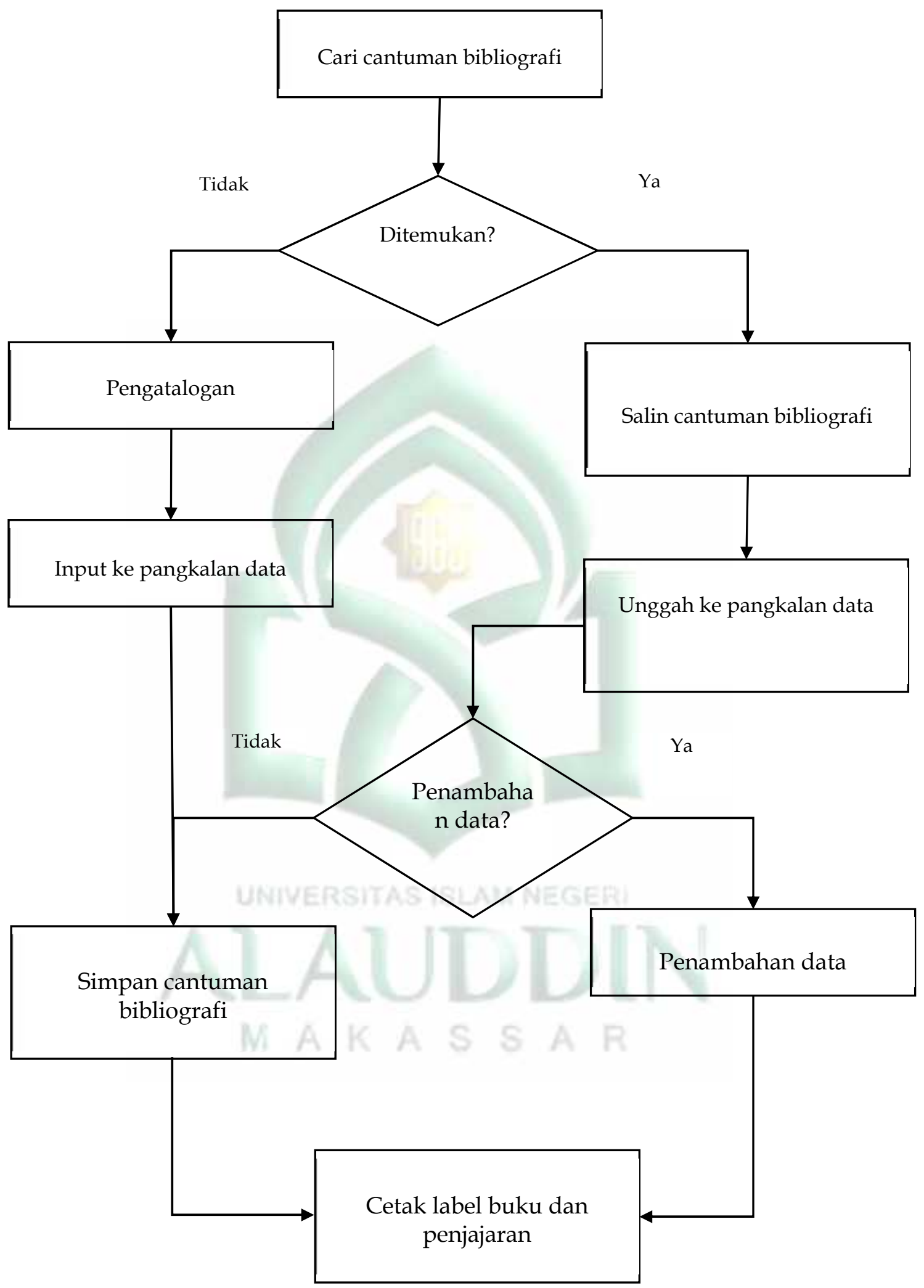

Gambar 1. Alur pengatalogan salin (Adaptasi dari Bapte, 2015) 


\section{HASIL DAN PEMBAHASAN}

\section{a. Perpusnas Sumber Pengatalogan Salin}

Perpusnas merupakan lembaga perpustakaan yang berada di level nasional. Salah satu fungsi dari Perpusnas adalah sebagai perpustakaan deposit. Melalui Undang-Undang Nomor 4 Tahun 1990 Tentang Serah Simpan Karya Cetak Dan Karya Rekam, Perpunas menjadi lembaga deposit karya cetak dan karya rekam Indonesia. Undang-Undang Nomor 43 Tahun 2007 Tentang Perpustakaan juga menguatkan fungsi Perpusnas sebagai perpustakaan deposit. Dengan berdasarkan dua undang-undang ini, Perpusnas menjadi lembaga yang bertanggung jawab dalam melakukan pengawasan bibliografi nasional.

\section{Undang-Undang Tentang Serah} Simpan Karya Cetak Dan Karya Rekam, atau yang sering disebut sebagai UU Deposit, merupakan kekuatan hukum yang paling kuat bagi Perpusnas untuk melakukan pengawasan bibliografi nasional. Terlepas dari beberapa penilaian untuk melakukan peninjauan kembali UU Deposit yang dinilai sudah tidak mampu mengakomodasi perkembangan yang ada, UU Deposit yang sudah ada ini sendiri belum terlaksanakan secara maksimal (Maryam, 2007). Pengawasan bibliografi nasional dinilai belum dilaksanakan secara maksimal. Para penerbit dan pengusaha rekaman belum banyak tersosialisasikan dan tersadarkan akan fungsinya pengawasan bibliografi nasional.

Melalui dua undang-undang ini, Perpusnas dimungkinkan mempunyai seluruh judul terbitan baik tercetak maupun terekam dari seluruh penerbit dan pengusaha rekaman yang ada di
Indonesia. Perpusnas juga dimungkinkan mempunyai seluruh judul karya warga negara Indonesia yang diterbitkan di luar negeri dan dimungkinkan mempunyai seluruh karya mengenai Indonesia yang diimpor. Kemungkinan-kemungkinan ini sudah diatur dalam dua undang-undang ini.

Dengan kemungkinan dimilikinya seluruh terbitan seperti yang diungkap, sudah selayaknya Perpusnas menjadi sumber dari pengatalogan salin. Saat ini, Perpusnas membuka metadata cantuman bibliografi hasil dari pengatalogannya. Siapa pun, baik organisasi atau individu, dapat mengunduh metadata dari setiap cantuman bibliografi koleksi Perpusnas. INLIS, sistem otomasi perpustakaan yang digunakan Perpusnas saat ini, memungkinkan untuk membuka metadata cantuman bibliografi.

\begin{tabular}{|c|c|c|}
\hline \multicolumn{2}{|c|}{ thestrots } & \multirow[t]{2}{*}{ Trmplan xatlog } \\
\hline sisther & $k x ; i$ & \\
\hline Coner: ip & 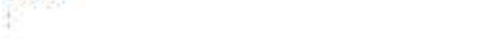 & Hot nats \\
\hline kat & : & Bsulw: \\
\hline (vilir & & \\
\hline iAPse & 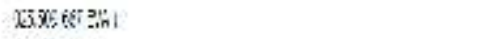 & Induh Katalsg \\
\hline एक्याओ & $\operatorname{Mentan}$ & \\
\hline ind & 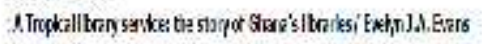 & 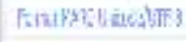 \\
\hline $\sin x+1$ & 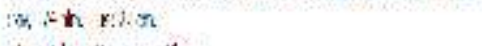 & Fomblazy. \\
\hline sten & 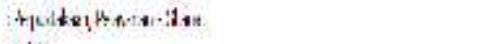 & Petetye: \\
\hline isis & ads & metint li:wig: \\
\hline & & tavilutation \\
\hline $\begin{array}{l}\text { Iniah } \\
\text { Esseapler }\end{array}$ & $: 3$ & 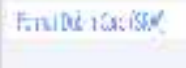 \\
\hline
\end{tabular}

Gambar 2. Tampilan cantuman bibliografi katalog online Perpusnas

Gambar 2 di atas adalah tampilan detail dari katalog online Perpusnas. Katalog online ini dapat diakses melalui alamat opac.perpusnas.go.id. Dari gambar di atas terlihat, di sisi kanan, terdapat menu untuk mengunduh metadata katalog dengan berbagai format, yaitu format MARC, MOD, dan Dublincore. Tiga format data ini dipilih karena tiga format data yang banyak digunakan oleh 
perpustakaan. Dengan demikian, keterbukaan Perpusnas dalam metadata ini dapat digunakan oleh perpustakaan, khususnya perpustakaan di Indonesia untuk melakukan pengatalogan salin.

Selain itu, Perpusnas juga menyediakan KIN online. Dalam pengantar di web KIN online, disebutkan bahwa KIN merupakan merupakan gabungan data katalog koleksi seluruh perpustakaan di Indonesia. Lalu disebutkan pula bahwa:

“Tujuan pembangunan KIN adalah agar masyarakat dapat menemukan data bahan perpustakaan yang diperlukannya, sekaligus mengetahui lokasi bahan perpustakaan tersebut. Dalam lingkup nasional KIN diharapkan dapat mencerminkan kondisi koleksi bahan perpustakaan dalam skala nasional. KIN dapat terwujud secara lengkap dan akurat jika seluruh perpustakaan di Indonesia bersedia berpartisipasi untuk memberikan atau menyediakan akses ke pangkalan data katalog koleksi perpustakaan. Pengembangan jaringan kemitraan dengan seluruh jenis perpustakaan di Indonesia sangat menentukan keberhasilan dalam menghimpun data KIN ini."

Melihat penjelasan ini maka jelas bahwa KIN bertujuan untuk menggabungkan katalog dari berbagai katalog perpustakaan seluruh Indonesia. Hal ini memungkinkan terjadinya cantuman bibliografi yang kaya. Walaupun ditemukan dokumen yang sama di beberapa perpustakaan, namun dengan kekhasan masing-masing kebijakan pengembangan koleksi perpustakaan di Indonesia seharusnya banyak akan ditemukan cantuman bibliografi yang tidak akan ditemukan di perpustakaan lain. Dengan demikian KIN dapat menjadi sumber pengatalogan salin.
Hal ini diperjelas oleh Isyanti (2011) yang menyatakan bahwa salah satu tujuan dari adanya KIN adalah menyediakan layanan pengatalogan salin bagi perpustakaan yang membutuhkan.

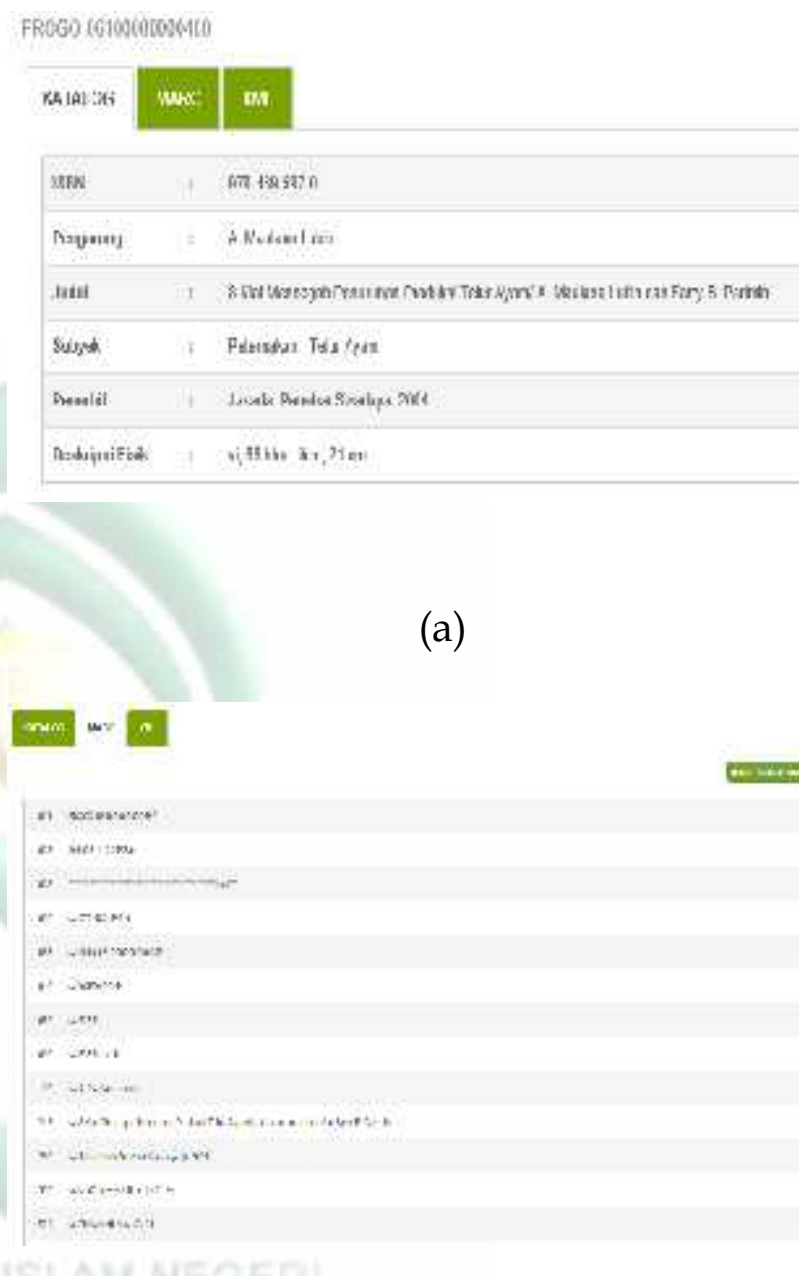

(b)

Gambar 3 (a) dan (b). Tampilan cantuman bibliografi KIN online

Dari gambar 3 di atas memperlihatkan tampilan detail dari cantuman bibliografi KIN online. KIN online dapat diakses melalui alamat kin.perpusnas.go.id. Di bagian atas terdapat pilihan sheet format MARC dan XML. Data yang di atas merupakan data dari katalog Perpustakaan Kabupaten Kulon Progo. Setelah memilih salah satu sheet tersebut maka di sisi kanan atas terdapat pilihan untuk mengunduh format yang 
dimaksud.

Satu lagi yang dapat digunakan adalah BNI online. Dalam web BNI online disebutkan bahwa "BNI merupakan kumpulan data bibliografis terbitan atau publikasi yang diterbitkan di Indonesia". Disebutkan lebih lanjut bahwa:

"BNI berfungsi sebagai sarana kendali bibliografis (bibliographic control) di Indonesia. Tujuan pembangunan BNI adalah untuk mengetahui kondisi penerbitan di Indonesia, mencakup jumlah penerbit yang ada, kuantitas terbitan dari waktu ke waktu, subjek atau topic atau genre yang paling banyak ditulis atau diproduksi. Tegasnya, kendali bibliografis dalam bentuk BNI ini diperlukan untuk mengetahui khasanah intelektual bangsa."

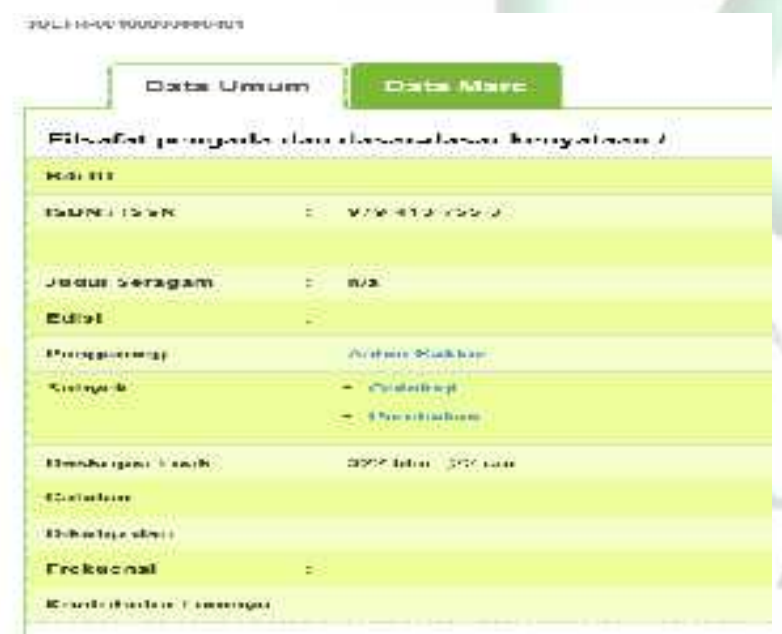

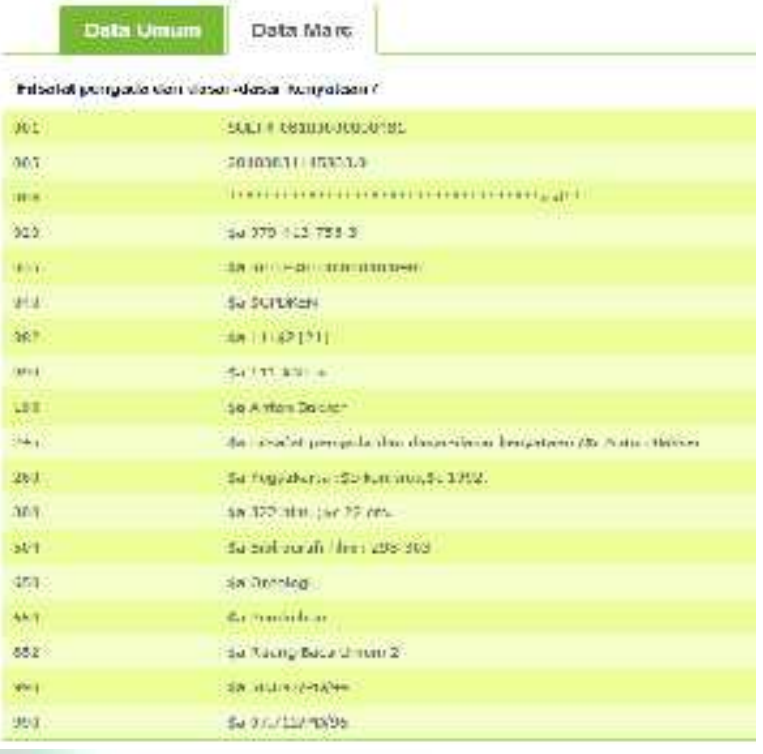

Gambar 4. Tampilan cantuman bibliografi BNI online

Gambar 4 merupakan tampilan detail cantuman bibliogri BNI online. Dalam gambar di atas, cantuman bibliografinya merupakan cantuman bibliografi dari perpustakaan umum Sulawesi Tenggara. Mirip dengan tampilan di KIN, terdapat sheet MARC yang dapat dipilih. Ketika dipilih akan keluar metadata dengan format MARC. Kekurangannya dalam BNI online ini tidak terdapat fasilitas unduh format.

\section{b. Sosialisasi Pengatalogan Salin}

Penulis mendapatkan masukan dari seorang teman yang bekerja di Bagian Pengolahan Bahan Pustaka Perpusnas, bahwa terdapat pustakawan senior merupakan ahli pengatalogan salin. Untuk itu pada tanggal 9 Mei 2016, penulis melakukan wawancara dengan pustakawan senior tersebut. Memang benar Perpusnas mempunyai metadata cantuman bibliografis yang diberikan secara gratis. Perpustakaan lain dapat mengambil metadata tersebut lalu menggubahnya sedikit sesuai dengan kebijakan organisasi lokal dan 
memasukkannya ke dalam pangkalan data mereka.

Terkait sosialisasi, merupakan hal yang kompleks karena ada faktor pembagian tugas dalam struktur di Perpusnas. Perpusnas -dalam hal ini Bagian Pengolahan Bahan Pustaka- sudah melakukan sosialisasi pengatalogan salin. Sosialisasi dilakukan melalui jalur formal maupun tidak formal. Tidak formal disini maksudnya sosialisasi dalam komunikasi informal dengan pustakawan yang bekerja di berbagai perpustakaan.

Sementara, untuk sosialisasi formal, Bagian Pengolahan bekerja sama dengan Bagian Kerja Sama Perpustakaan dan Otomasi. Kedua bagian ini bekerja sama dalam melakukan Bimbingan Teknis ELibrary dimana salah satu muatannya adalah mengajarkan penggunaan sistem otomasi perpustakaan yang dikelola Perpusnas, yaitu INLIS (Integrated Library Sistem) Lite yang digunakan oleh perpustakaan daerah. Dalam INLIS Lite ini, terdapat fasilitas untuk menggunakan pengatalogan salin. Dengan demikian, sosialisasi dilakukan satu paket dengan sistem otomasi perpustakaannya.

Ketika ditanya lebih lanjut, bagaimana rencana sosialisasi ke depan, peneliti dirujuk kepada atasannya. Setelah digambarkan secara garis besar bahasan pembicaraan peneliti sebelumnya, dinyatakan bahwa sosialisasi pengatalogan salin bukan merupakan tugas pokok dan fungsi (tupoksi) Bagian Pengolahan Bahan Pustaka. Kegiatan tersebut merupakan Tupoksi Bagian Kerja Sama Perpustakaan dan Otomasi.

Atas dasar ini, peneliti mewawancarai Kepala Bidang Kerja Sama Perpustakaan dan Otomasi. Ketika dikonfirmasi tuposi sosialisasi pengatalogan salin, diiyakan bahwa kegiatan tersebut merupakan tupoksi bagiannya. Dijelaskan bahwa pengatalogan salin merupakan bagian dari pengembangan e-library yang dicanangkan oleh Perpusnas.

Perpusnas dalam rencana kerja pengembangan e-library 2010-2014 memfokuskan pada integrasi pangkalan data dari sebanyak mungkin dari seluruh perpustakaan di Indonesia. Hal ini dapat dilihat dalam KIN dan BNI yang sudah online. Dengan mendorong pengintegrasian pangkalan data dari berbagai perpustakaan, Perpusnas menawarkan pangkalan data yang besar yang diharapkan mampu mencakup bibliografi yang ada di Indonesia. Dengan demikian, dengan fasilitas di KIN dan BNI yang dapat mengunduh metadata dari suatu dokumen, maka pengatalogan salin dapat dilakukan oleh banyak perpustakaan.

Sosialisasi yang dilakukan adalah sebagai berikut:

\section{1) Workshop}

Kegiatan workshop dilakukan untuk memfokuskan pada urusan teknis. Target pesertanya adalah para pustakawan dari berbagai perpustakaan di seluruh Indonesia. Dalam workshop, materi yang berikan tidak berhenti pada level konseptual. Di sini juga diberikan keterampilan teknis yang diperlukan dalam pengembangan e-library yang merupakan paketan dari pengatalogan salin.

\section{2) Lokakarya}

Kegiatan lokakarya dilakukan untuk memfokuskan pada urusan kebijakan dan pengambilan keputusan. Target pesertanya adalah para pimpinan 
perpustakaan termasuk pimpinan organisasi yang membawahi unit perpustakaan. Jika para pustakawan yang berada di level operasional sudah memahami dan mampu mengoperasionalkan e-library, maka pimpinan harus mendukung dan menelurkan kebijakan yang sesuai. Faktor pimpinan sangat berpengaruh, karena kuasa anggaran, kegiatan, sumber daya manusia dan lain-lainnya berada di bawah kendalinya. Harapannya melalui lokakarya yang dilakukan, pimpinan akan mendukung penuh pengembangan $e$ library nasional dengan pemahaman dan didasari kesadaran kebutuhan pengembangan e-library yang kuat.

\section{3) Bimbingan Teknis}

Kegiatan bimbingan teknis dilakukan sebagai supervisi dari jalannya pengembangan e-library. Jadi bimbingan teknis diberikan kepada perpustakan yang sudah memutuskan untuk mendukung dan menerapkan pengembangan e-library dalam perpustakaannya. Bimbingan teknis ini lah yang merupakan kerja sama dari Bidang Kerja Sama Perpustakaan dan Otomasi dengan Bidang Pengolahan Bahan Pustaka.

Selanjutnya, pada tahap rencana kerja 2015-2019, pengembangan e-library memfokuskan pada tahap menciptakan interoperabilitas dari pangkalan data yang dipunyai perpustakaan di Indonesia. Interoperabilitas dilakukan sebagai lanjutan dari integrasi. Integrasi memerlukan kemampuan membaca berbagai format metadata yang digunakan oleh perpustakaan. Kemampuan membaca ini yang dikenal dengan istilah interopabilitas.

Di awal dari rencana kerja ini,
Perpusnas sudah meluncurkan Indonesia OneSearch. Indonesia OneSearch ini merupakan tampilan kedua dari KIN dan BNI dengan sudah ditambahkan pangkalan data yang full-text. Indonesia OneSearch ini menggunakan protokol OAI-PMH atau the Open Archives Initiative Protocol for Metadata Harvesting. OAI-PMH ini memungkinkan untuk mengambil metadata dari berbagai format yang digunakan pangkalan data.

Menurut Pendit (2007), OAI-PMH ini adalah semacam standar yang dapat diikuti oleh para pembuat antarmuka web bagi kepentingan penyimpanan dan penemuan kembali e-print (dokumen digital). Sebagai suatu standar, OAI-PMH merupakan salah satu contoh upaya interoperabilitas yang cukup berhasil. Jika pangkatan data dokumen digital mengikuti standar OAI-PMH, maka mesin pengumpul (harvesters) dapat menarik informasi metadata dokumen digital tersebut.

\section{c. Penggunaan Sumber Pengatalogan Salin}

Sumber pengatalogan salin sudah diberikan dan juga telah dilakukan sosialisasi serta bimbingan teknis. Lalu bagaimana penggunaan sumber pengatalogan salin yang telah disediakan oleh Perpusnas. Berdasarkan informasi yang diberikan, nampak beberapa pustakawan menggunakan Perpusnas sebagai sumber pengatalogan salin. Hal ini diketahui melalui komunikasi informal yang dilakukan oleh beberapa pustakawan Bagian Pengolahan Bahan Pustaka Perpusnas dengan berbagai pustakawan di perpustakaan yang menanyakan bagaimana penggunaan sumber pengatalogan salin Perpusnas, contohnya Perpustakaan Institut Pertanian Bogor. Namun tidak diketahui 
apakah pengatalogan salin ini telah menjadi kebijakan lembaga perpustakaan atau hanya menjadi inisiatif individual dari pustakawan di bagian pengolahan saja.

Peneliti sendiri ketika menjadi pustakawan di perusahaan swasta juga melakukan pengatalogan salin dengan sumber dari Perpusnas. Proses yang dilakukan oleh pustakawan dalam melakukan pengatalogan salin tersebut adalah mengunduh format MARC lalu memasukkannya dalam pangkalan data di perpustakaannya. Selanjutnya mereka melakukan beberapa penyesuaian berdasarkan kebijakan perpustakaannya.

Penyesuaian metadata yang telah disalin adalah termasuk melakukan pengeditan jika ada kesalahan pengetikan. Menurut Beall dan Kafadar (2004), perpustakaan yang melakukan pengatalogan salin dapat juga menyalin kesalahan pengetikan yang telah dibuat dalam cantuman. Kesalahan pengetikan yang terjadi dalam pengatalogan umumnya pada pengetikan deskripsi dan pengetikan coding (Bade dalam Beall dan Kafadar, 2004). Dari 500 cantuman bibliografis yang dijadikan sampel, Beall dan Kadafar menemukan sebesar 35,8\% cantuman bibilografis dibenarkan dari kesalahan pengetikan. Sementara $64,2 \%$ cantuman bibliografis lainnya tidak pernah dibenarkan dari kesalahan yang ada.

\section{PENUTUP}

\section{a. Kesimpulan}

Sumber pengatalogan salin yang disediakan Perpusnas, yaitu katalog online yang dapat diakses di opac.perpusnas.go.id, katalok induk nasional yang dapat diakses di kin.perpusnas.go.id, dan bibliografi nasional indonesia yang dapat diakses di bni.perpusnas.go.id. Ketiga sumber ini merupakan keluaran dari fungsi pengawasan bibliografi yang dilakukan Perpusnas.

Fungsi pengatalogan salin tergabung dalam fungsi e-library yang dikembangkan Perpusnas. Saat ini, pengembangan $e$ library masuk dalam tahap kedua, yaitu tahap yang memfokuskan pada interopabilitas setelah sebelumnya dalam tahap petama memfokuskan pada integrasi. Sosialisasi termasuk dalam pengembangan e-library. Sosialisasi menyasar kepada ke setiap level dalam perpustakaan, yaitu level pengambil kebijakan dan pelaksana kebijakan. Pengembangan ini di Perpusnas dilakukan oleh Bidang Kerja Sama Perpustakaan dan Otomasi.

Sumber pengatalogan salin Perpusnas sudah digunakan oleh beberapa perpustakaan perguruan tinggi. Penggunaan ini dipengaruhi kebijakan perpustakaan dimana pustakawan bekerja. Walaupun secara teori pengatalogan salin mempunyai banyak keuntungan, aplikasinya secara umum, baik di Indonesia maupun di luar Indonesia, ternyata masih jarang perpustakaan yang melakukan pengatalogan salin.

\section{b. Rekomendasi}

Dari penelitian kecil ini, direkomendasikan bahwa perlu dipenelitian lebih lanjut bagaimana kondisi pengatalogan salin di perpustakaan Indonesia, misalnya dengan melakukan survei atau jika ingin memahami lebih mendalam dapat dilakukan studi kasus pada perpustakaan yang telah melakukan pengatalogan salin 
secara resmi.

\section{DAFTAR PUSTAKA}

Bapte, V.D. (2015). Copy Cataloguing through SOUL 2.0. Journal of Library $\mathcal{E}$ Information Technology, Vol. 35, No. 5, pp. 330-334

Beall, J., \& Kafadar, K. (2004). The effectiveness of copy cataloging at eliminating typographical errors in shared bibliographic records. Library Resources \& Technical Services, 48(2), 92

Hess, Julia I. (2015). Managing Change in Copy Cataloging Procedure at the University of San Diego. Technical Services Quarterly. 32(4): 373-382, DOI: $10.1080 / 07317131.2015 .1059676$

Isyanti, D. (2011). Penerapan IndoMARC sebagai format standar data bibliografis dalam pembangunan katalog induk. Prosiding Konferensi Perpustakaan Digital Indonesia ke-4.

Mustafa, B. dan Raharjo, B.C. (2011). Interopabilitas copy cataloging dalam sistem union katalog. Prosiding Konferensi Perpustakaan Digital Indonesia ke-4.

Maryam, S. (2007). Sikap penerbit buku Islam di Jakarta terhadap UU RI No 4 tahun 1990 dan hubungannya dengan pengawasan bibliografi buku-buku Islam di Indonesia. Tesis. Depok: Universitas Indonesia.

Pendit, P.L. (Desember 2007). Serba open di jagat informasi: memahami OA, OAI, dan OAIS dan hubungannya dengan kemelekan informasi. Makalah Seminar dan Pelatihan: Kemelekan Informasi, Keberlangungannya dari Sekolah ke Perguruan Tinggi. 10-12 Desember 2007 di Universitas Pelita Harapan.
Svenonius, E. (2000). The Intellectual foundation of information organization. London: The MIT Press. 